\title{
Brides, maids, and prostitutes: reflections on the study of 'trafficked' women ${ }^{1}$
}

\author{
Nicole Constable, University of Pittsburgh
}

\section{Introduction}

Over the past several years, some feminist scholars of migration have begun to argue that it makes sense to talk about the migration of 'prostitutes,' 'maids,' and 'mail order brides' as if they were all part of the same larger phenomenon (Maher 2003; Ehrenreich \& Hochschild 2004). I agree that it is sometimes useful to consider these three types of gendered migration together, but my own starting point and my argument in this essay takes a different focus and point of departure. ${ }^{2}$ Instead of arguing that the three separate literatures on what I prefer to call domestic workers, sex workers, and correspondence brides are too separate and would benefit from being combined, I am concerned with the potential for unwarranted blurs — or fuzzy shadow lines-between the three categories. I am troubled by the ways in which different types of gendered migration are sometimes blurred together and treated too much as though they are one and the same, in academic, popular, and activist literatures. Some academic literature and much activist literature that deals with multiple forms of women's migration prematurely assumes that they are part

\footnotetext{
${ }^{1}$ This essay was first prepared for The International Migration of ‘Traditional Women’: Migrant Sex Workers, Domestic Workers, and Mail-Order Brides in the Pacific Rim, a conference at the Center for Comparative Immigration Studies, U.C. San Diego, October 23-26, 2003. I am grateful to Kristen Hill Maher and the participants. A revised version was presented at the Eighth Women in Asia Conference, at the University of Technology, Sydney, September 26-28, 2005. My sincere thanks to Devleena Ghosh and Barbara Leigh for inviting me, Joseph Alter and Kevin Ming for their comments, S. Carole Vance for inspiring me to think about trafficking, and to the migrant women whose experiences have deeply influenced my view of the world.

${ }^{2}$ There are a growing number of recent studies that criticize popular notions of trafficking, that do not blur boundaries or that do so in productive ways (e.g., Cheng 2002; and contributors to Piper \& Roces 2003).
}

PORTAL Journal of Multidisciplinary International Studies Vol. 3, no. 2 July 2006

ISSN: 1449-2490

http://epress.lib.uts.edu.au/ojs/index.php/portal 
of a common phenomenon, one that can most simply be glossed as 'trafficked women.'

My second and related concern has been-especially in the case of correspondence marriages - that some authors have focused on, or reproduced in their own work, simplistic stereotypes or an imagined fantasy of 'mail order brides' with relatively little attention paid to the variations in the circumstances, forms of introduction, and actual experiences of couples who have met through correspondence and eventually married. Therefore, before considering productive comparisons, it is important to carefully consider the variations within each 'category' of migrant woman, and the limitations of defining them as a category in the first place.

My aim here is to reconsider some of the scholarly and popular depictions of so-called 'mail order brides' as 'trafficked' women; to question what I consider the warranted and unwarranted blurs that subtly or explicitly enter some of the scholarly and activist literature on 'mail order brides'; and to highlight heterogeneity in the experiences, circumstances, and expressions of agency of women who meet men through correspondence. The literature on sex workers has influenced my thinking about correspondence marriage, not because brides and sex workers are fundamentally alike, but because they are both subjects of the wider discourse on trafficking, women's agency, and women's victimization. I aim to highlight the weaknesses of a trafficking framework from an ethnographic perspective, and point to some of the ways that theoretical issues raised in the sex worker literature might apply to the study of correspondence marriages. ${ }^{3}$ Despite important theoretical insights that can come from a combined discussion of sex workers, domestic workers, and foreign brides, and despite many similarly structured patterns of inequality, I urge caution.

\section{Women's emigration to rich countries}

Because migrant sex workers, maids, and correspondence brides often (but not always)

\footnotetext{
${ }^{3}$ This essay draws from research I began in 1998 among women and men who met through correspondence and from research conducted among Filipina domestic workers in Hong Kong in the early 1990s.
} 
follow the broader patterned movement of women from poorer, so-called Third World countries of the less developed global South, to wealthier First World or more developed countries of the global North, they are often assumed or implied to share common structures of inequality that define, constrain, and propel their mobility. The mobility of women from poorer parts of Asia (e.g., the Philippines, Indonesia, Thailand, Sri Lanka, India) who perform the reproductive labor for people in wealthier regions (e.g., Hong Kong, Taiwan, Singapore, Western Europe and the Middle East) is well documented (Constable 1997, 2003a, 2003b, 2005a, 2005b; Parrenas 2001; Ehrenreich and Hochschild 2002; Gamburd 2000; Kempadoo and Doezema 1998). But despite some broader gendered migration patterns, the overall theme lends itself too easily to the wellaccepted logic of a more simplistic modernization narrative: of course poor women will want to move from a poor or 'backwards' country to work for or marry a richer person in a more 'modern' country. The structural inequality of such a situation provides a common and readily accepted logic for the growing pattern for female labor and marriage migration. This logic is not necessarily wrong, but it is not the only way to tell and understand the story. Moreover, if it is read as the story, it obscures significant variations among and between women and through time.

One problem with such a narrative is that factors that do not fit so clearly may be obscured or ignored. For example, a simple modernization narrative risks obscuring the fact that Filipinas who work as maids in Hong Kong (and elsewhere), are not usually among the poorest or least-educated women from the Philippines, and that many do not consider earning money their only or even their primary motivation. It can obscure the fact that many correspondence brides from China are not so young and not so poor, but are often urban professionals in their late thirties or forties, many of whom are divorced. Such a narrative often obscures non-material motivating factors for emigration. A desire to be married, to escape familial problems, or for love, romance, or compatibility, may be among the non-material motivating factors for women who seek to meet foreign marriage partners through correspondence. Like many Filipina prospective brides, given a choice, Chinese women often voice their preference for having their foreign husbands come and live in their country, rather than emigrate to the West. 
The pattern of Filipina maids being more educated than their employers, or of professional Chinese or Vietnamese women marrying working class Western men (Thai 2002; Constable 2005a), reveal problems with maintaining the popular fiction of poor and desperate so called 'traditional' women emigrating to the West. Such a narrative may lead us to take at face value images that women promote of themselves as 'traditional' women, actively and consciously downplaying their education and their worldly experiences in order to attract prospective employers or spouses. On the other hand, assuming that all prospective employers and spouses want 'traditional' Asian wives or workers is also inaccurate. Chinese employers in Hong Kong before 1997, for example, often expressed a strong preference for hiring Filipinas over rural mainland Chinese women as domestic workers precisely because Filipinas were conceived of as more modern, more Western, better educated, better versed in English (and could tutor children), and thus better at serving the needs of cosmopolitan employers (Constable 1997). Whereas many US men seeking marriage partners hope to meet women with 'traditional family values' and expect to find such values in women from more remote and less cosmopolitan regions of the Philippines, others sought to correspond with and marry educated and professional Chinese women or Filipinas because they thought they would be a better match or better suited to a middle-class American lifestyle. Some men expected such women to be less 'desperate’ to emigrate, and to have more sincere marital objectives (Constable 2003a).

Another reason why the South to North migration narrative is troubling is because it lends itself too easily to the logic of a trafficking discourse, to a view of women as victims, and to a fundamentally anti-immigration stance. Such a narrative suggests overall that women are victims whether they know it or not, and it obscures some of the ways they express resistance, exert influence and create change. It thus makes it difficult to imagine any good migration. It also lays the foundation for an attempt to determine which women are innocent victims (deserving and worthy of protection by virtue of their 'coercion') and which are not. 
Jo Doezema’s insightful argument that the twin concepts of forced versus voluntary prostitution have lost their utility because they constantly resuscitate the dichotomous notion of innocent and coerced women who deserve rescue, and immoral women who deserve what they get, can be applied to foreign brides as well (1998). In the case of foreign brides, such dichotomous logic relies on a presumed distinction between naive and innocent women who are lured or coerced into marriages on false pretenses but have pure marital motives, versus those who are active agents who voluntarily enter into marriage, knowing what they are getting into, and whose marital motives are deemed questionable or too opportunistic.

In the United Nations Trafficking Protocol (article 3), trafficking is defined as 'the recruitment, transportation, transfer, harboring or receipt of persons, by means of threat or use of force or other means of coercion, of abduction, of fraud, of deception, of the abuse of power or of a position of vulnerability...' This definition is sometimes interpreted so broadly as to include almost anyone who emigrates from global South to North. It can be used to support the notion that all women from poorer parts of the world have been, in a sense, 'coerced'(or are 'vulnerable') — by virtue of fundamental global patterns of inequality-into migrating to wealthier parts of the world for work or marriage. This definition also begs the question of who exactly qualifies as 'coerced' or 'vulnerable.' Such a question, however interesting, may be misdirected. A wealthier, better-educated, woman in her forties from Manila or Beijing may be assumed to be less vulnerable to exploitation than a very young, less educated woman from a poor rural village, but surely neither woman should be denied a visa or legal privileges and protections on the basis of age, education, or social background.

Several examples help to illustrate the way in which the concept of trafficking is uncritically applied to foreign brides. In Mail-Order Brides: Women for Sale (1994) Mila Glodava and Richard Onizuka discuss what they consider an obvious connection between 'mail order brides' and trafficking. They applaud the 1990s spotlight on 'mail order brides' and explain, 'this exploitation of women carries heavy societal consequencesthe continued degradation of women and oppression of the weak, which can promote 
other forms of sexual exploitation such as pornography, pedophilia, white slavery and prostitution' $(1994,6)$. Their argument is built on the assumption that correspondence brides are literally 'sold' to western men who 'buy' brides. Such a definition, which highlights the commodification of women and blurs them with sex workers and slaves, is not uncommon. The Coalition Against Trafficking in Women (CAT-W) and the Philippine Women Center of British Columbia (PWC) also define 'mail-order brides' as 'trafficked women,' a category in which they include 'domestic workers, mail-order brides, prostitutes and other Filipino women who are forced to emigrate as part of globalization' (PWC 2000, 1; Barry 1992). ${ }^{4}$

According to the PWC, a 'mail order bride' is the result of a 'formal transaction between a man and a woman from different countries, usually brokered by an agent, who is part of the mail-order bride industry, via catalogs or the Internet. The term...[applies] to situations where men go to the Philippines with the intention of finding a wife' and includes 'Filipino women who have been introduced to Canadian husbands through informal networks of family and friends' $(2000,1)$. The PWC also counts as 'mail order brides' women who have met their husbands through computer dating in Canada and women who have married their employers (49). Their definition is so broad that it is difficult to imagine any form of Filipina migration that would not be trafficking. Like Glodava and Onizuka, the PWC makes no case for determining that some foreign brides are trafficked and others are not, nor do they attempt to distinguish between those who were coerced and others who were not.

Glodava and Onizuka cite several 'unsuccessful' 'case stories,' all of which involve abuse and most of which end in divorce, to illustrate some of the difficulties faced by 'mail order brides’ as trafficked women. These include the story of Chita, a 45-year old school teacher in the Philippines, who was 'considered an old maid by her friends and colleagues and had become increasingly anxious to get married' $(1994,69)$. Chita envied

\footnotetext{
${ }^{4}$ Organizations such as CAT-W reject the notion of 'sex work' and consider all prostitution a form of violence against women. It thus furthers their agenda to blur the boundaries and to swell the ranks of socalled 'trafficked' women.
} 
her friends with US husbands, hoped to meet a man who could help support her family, and submitted her photograph to an introduction agency. After corresponding with Dean for a year and a half, they met in person and eventually married. In the United States, Chita was faced with caring for three abusive stepchildren. The children 'treated her like a maid' and Dean allowed it (70). Eventually she 'ran away to a shelter,' and as Glodava and Onizuka write, she is 'now working and happy to be free of her abusive situation. She has divorced her husband and has acquired [US] permanent residence’ (70). Catherine was 'an unwed mother who had a very good job in advertising in Malaysia' (70) when she decided - partly as a joke - to submit her name and photograph to a friend's introduction agency. After almost six months of correspondence with John, he came to Malaysia and they were married. In the United States, John began treating her violently, and 'brought his mistress home' (71). After a lengthy trial, she divorced John and 'is looking forward to becoming a citizen and bringing her son and his wife to the United States' (72). Amor 'was 42 when she married a corporate lawyer named Don.' She had been 'a chemist working for a prestigious pharmaceutical company in Manila when Don saw her photograph in one of the mail-order bride catalogs’ (72). Like John, Don 'started bringing home his mistress.' When the mistress moved in, Amor decided to leave him, despite the stigma of a failed marriage, she moved to California and decided against reconciliation (73).

These cases are used by Glodava and Onizuka to illustrate the abuses and difficulties that 'mail order brides' face as ‘trafficked' women, but they also reveal other patterns that the authors do not discuss. Like many of the prospective Chinese and Filipina brides I encountered during my research on correspondence introductions and marriage between 1998 and 2001, Amor and Chita were both considered 'too old' to marry well in the Philippines, and like Rosie, a Filipina unwed mother I knew well, Catherine's status as an unwed mother reduced her prospects for a favorable marriage locally. Although Chita cited economic need as a factor in her desire to marry a wealthy American, Catherine and Amor had relatively good jobs. Like many of the women I encountered, it is difficult to reduce these women's motives to economic desperation. The women I met in the late 1990s had a number of reasons for seeking to marry foreigners. Economics were rarely 
the primary or the sole motivating factor (see also Nakamatsu 2003, 183). Their interest was tied at least in part by a desire to be married, and to achieve marital subjectivity, since remaining single was looked down upon. Their non-material reasons included a desire for love and compatibility, and a desire to meet a man who would treat them as equals. Such reasons were not necessarily conceived of as separate from economic or material considerations.

Like the women I knew, Amor, Chita, and Catherine all took the initiative to list their names and photographs with an introduction agency and they made decisions about who to write to. Contrary to the common assumption that intra-ethnic marriages that are based on introductions by friends or family members provide a greater safety net than those based on impersonal introductions (Maher 2003, 15), women I spoke to pointed out the 'freedom' afforded to them by Internet or printed catalog introductions. As one explained, when a family member or friend serves as matchmaker, it is difficult to say no, but when you meet someone through E-mail or the Internet, you are free to say no, withhold your address, tear up his letter, give a false name, or never correspond again. Moreover women who marry within an ethnic community might find community support, but they can also be pressured not to air their dirty laundry at the risk of shaming not only themselves and their husbands, but also the wider ethnic community (Narayan 1995). Given the stigma associated with divorce in the Philippines, and the sense that it is the woman's responsibility to make a marriage succeed, had Amor, Catherine or Chita married an overseas Filipino, they could have faced greater community or familial pressure to remain in an unhappy marriage. Moreover, an intra-ethnic marriage, for example between a mainland Chinese woman emigrant and a Chinese American man, given the cultural, regional, and possible class differences, would not necessarily result in greater compatibility than a marriage between a Chinese woman and a white American (Chin 1994).

Given the initiative that Chita, Catherine, and Amor express in the process of seeking a husband, it is difficult to see them as passive. In the end, after facing difficulties in their marriages and receiving support from friends or women’s activist organizations, all three 
women remained in the United States, found jobs, and took the route of permanent residence and eventually, perhaps, citizenship. Yet Glodava and Onizuka use these cases to illustrate the plight of 'trafficked' women who are 'bought' and 'sold', rather than their agency. In such cases, I would argue, the notion of 'trafficking' deters from a clear understanding of their situations. They experienced emotional and physical abuse, but they were not 'bought or sold.' A deeper understanding of their situations is gained from an awareness of structural factors (economic ones), gendered assumptions about work, and the vulnerability of immigrant brides. In such cases, a trafficking framework obscures their agency and the important factors underlying their decisions to emigrate, depicting them instead as willing victims.

\section{Discursive blurs}

Some authors who do not utilize the term 'trafficking' nonetheless highlight certain commonalities or connections between maids, sex workers, and brides without adequately considering differences and variations and the implications of such blurs. Roland Tolentino’s article, 'Bodies, Letters, and Catalogs: Filipinas in Transnational Space' (1996) serves as an example of the blurring of boundaries between several categories of women workers and migrants.

Tolentino's article is a fascinating and insightful discursive analysis of what he calls the 'geopolitics of Filipinas in transnational space, specifically focusing on the problematics of the mail-order bride phenomenon as a social and political practice' (1996, 49). He analyses 'mail-order brides' as 'bodies in transnational space,' alongside the bodies of Filipina maids or helpers, sex workers, sweatshop factory workers, and nurses. As he explains, all are linked to Philippine political economy, colonial and post-colonial history, race relations, and western sexual fantasies about Asian women. Tolentino aptly observes that Filipino women's racial, national and gender identities are connected to their opportunities for mobility as wives, sex workers, and maids.

Insightful and important in many ways - contributing to a large body of literature that examines ‘mail order bride catalogs' (e.g., Halualani 1995; Wilson 1988; Villapando 
1989) or local host communities' discourses about 'mail order brides,' maids and sex workers (e.g., Holt 1996; Robinson 1996; Suzuki 1999, 2005), and linking it to a wider concern about gender and transnationalism - the article nonetheless illustrates the risk of unwarranted blurs between Filipina workers of various sorts, and wives. He focuses on discursive dimensions of 'mail order brides,' and his stated goal is not 'to construct a rescue narrative nor a victim paradigm for the mail-order bride; both inevitably position women as oppressed, taunting liberation as key to the questions "What is to be done?”...' Instead, his hope is for 'other interventions to occur which, in turn, may lead toward some theoretical and practical empowerment tactics for the actual marginalized bodies/voices who experience the effects of colonial and neocolonial histories in their daily struggles’ (1996, 51-52).

One of the key threads that ties Tolentino's essay together is that of the sexuality of Filipina women. He suggests that Filipina brides (or more specifically the discourse about Filipina brides) is linked to their sexuality, sex workers and 'hospitality girls' in military brothels, maids, and sweatshop workers. However, his study stops short of actual ethnographic analysis or any attempt to integrate the voices and discourses of women who would question, debate, or dispute, many of these commonalities. The essay thus conveys a generalized message about the overall commodification and exploitation of Filipina women. The 'mail order brides' in his article, may be discursive representations of bodies in transnational space, but they are nonetheless depicted as commodities that are victimized by western men, and that are primarily understood as little different from exploited domestic workers and abused entertainers and prostitutes.

Tolentino avoids the term 'trafficking,' but his work contains and reinforces a similar blur to that which is found in the work of activist scholars and activist organizations. The idea that 'mail order brides,' prostitutes, and maids are trafficked women or that they are somehow alike as 'marginalized bodies' in transnational space, reinforces the sense that their similarities are greater than their differences. Such studies, to borrow from Chandra Mohanty, homogenize and discursively colonize Third World women, rendering them all as victims (1991). Both the discursive analysis of catalogs and the trafficking literature on 
'mail order brides' ignore women's own views of themselves as anything other than victims. Defined solely or primarily on the basis of their presumed victim status, maids, sex workers and correspondence brides inevitably_but inaccurately—blur together. It is hard to imagine how the 'marginalized bodies/voices' of Filipina brides might enter such a discussion given that they would disagree with many of the ways Tolentino has described them.

\section{Labels}

As an ethnographer, I am particularly interested in people's own use of labels and their responses to the labels that others impose on them, and especially people's rejection or critique of externally imposed labels. In the course of research among Filipina domestic workers in Hong Kong and among women involved in correspondence relationships, I noticed disjunctures between women's own labels, their understandings of themselves, and their roles as prospective brides and domestic workers on the one hand, and the labels that outsiders (including employers, government organizations, employment agencies, and researchers) imposed on them. Politically active maids in Hong Kong preferred the term 'domestic worker' (DW) to 'domestic helper' (DH) or 'maid.'5

Given the variety of terms people use to refer to themselves, and the different opinions about such terms, it is difficult to find one term that satisfies everyone. Nevertheless, it is important to consider how labels both reflect and can come to constitute a certain reality. The terms 'trafficking' and 'mail order bride' are linked to certain assumptions about women's victim status and their commodification. They fit with and reinscribe preexisting demeaning images of Asian women as submissive 'lotus blossoms' or sly 'dragon ladies' (Tajima 1989; Marchetti 1993). It is thus important to ask whether those we write about identify with the labels we use, and if not what are the implications of

\footnotetext{
5 'Domestic worker' reflects a political stance and is considered preferable to derogatory or diminutive terms such as 'maid' or 'helper.' Although not embraced by all Filipina maids, DW implies agency, activism and consciousness about workers' rights. DW indicates resistance to the notion of a maid as a victim, and an awareness of the unequal conditions that make victimization and exploitation possible. As such, some women initially thought of themselves as 'maids' or 'helpers' but after experiencing difficulties or becoming familiar with problems faced by workers, embraced the label DW. As of the mid-1990s, even the most activist domestic workers did not consider migrant domestic workers 'trafficked.'
} 
using them anyway?

I met women in Hong Kong who unselfconsciously referred to themselves as 'maids' or 'helpers,' although most activist women preferred the term domestic worker, but I never met women involved in correspondence relationships who referred to themselves as 'mail order brides.' The English term is well known and carries very negative connotations in the Philippines; in China in the 1990s it was virtually unknown. When I explained the notion of 'mail order' to Chinese women, they laughed or expressed offense at the idea that they were like commodities to be bought or sold.

In the Philippines 'mail order bride' is used by staff members of organizations such as the CFO (Commission on Filipinos Overseas) to refer to women who meet spouses through correspondence. This carries strong implications about the commodification of women, the commodification of the process of introductions, and trafficking. Women I met in the Philippines who were participating in the mandatory CFO 'Pre Departure Seminar' for wives or fiancées of foreign nationals were shown documentary videotapes about women who had been horribly abused by their foreign husbands. These women were identified as 'mail order brides.' One CFO staff member unofficially explained that the seminar was designed to establish which women really knew their husbands and which were 'mail order brides' thus establishing a connection between the term and the likelihood or possibility of experiencing domestic abuse.

The term 'mail order bride' is commonly used in the United States and Australia, but is rarely used by the men and women themselves. A US Department of Justice report, International Matchmaking Organizations: A Report to Congress (USDOJ-INS 1999), unabashedly uses the term, as does the appendix to the report entitled 'The Mail Order Bride Industry and Its Impact on Immigration’ (Scholes 1999). Of the dozens of men I encountered who were involved in correspondence relationships, most rejected the term and were critical of its use. They associated it with sensationalist media representations of correspondence marriages and with activist and feminist critiques of cross-border 
marriages as a form of trafficking. Many US-based introduction agencies have also widely rejected and criticized the term.

The term 'mail order bride' is problematic for many reasons (Julag-Ay 1997). Although it highlights the way in which images of women can be commodified by commercial introduction agencies, this can overshadow the fact that an increasing number of men are also listed on the websites and catalogs. As Kathryn Robinson reminds us (2001), brides are not simply 'bought and sold' although their images may be. Tolentino writes that, 'both bride and groom bind themselves into a contract of marriage without physically seeing each other' $(1996,60)$ and that 'the First World groom and Third World bride will most likely meet for the first time a few days before their marriage' (60). Both such statements reflect and reinforce deeply ingrained stereotypical assumptions about 'mail order brides,' but neither statement is supported by empirical research. In order to qualify for a US 'fiancée visa,' a couple is required by law to have met in person. There are rare exceptions in the case of religious prohibitions or if one partner is too ill or incapacitated to travel. Most couples I knew had met several times in person and corresponded for over a year before they married.

The term 'mail order bride' — with its implications of 'buying' a wife—also helps explain why textual analyses of so-called 'mail order bride catalogs' often impose a sexual reading onto images that appear in actuality to be very innocent, more reminiscent of images we might find in a school yearbook or in a passport (Wilson 1988, 120-21). Regardless of the innocent looking photographs reprinted in his article, Tolentino writes that catalogs are ‘torn between’ representing women as ‘hookers and virgins' although they 'aim to make clear the distinction between the two' $(1996,69)$. From the photographs he presents, however, there is little sign of 'hookers.' The catalogs may depict innocent-looking women, but they nonetheless recall-supposedly in men’s minds - images of sex tours and Asian prostitutes. In contrast to Tolentino’s assertion, most men I knew made a point of distancing themselves from women who might be remotely involved in the sex or hospitality industry, and most claimed to be looking for 
good wives with strong 'family values.'

Like the term 'trafficking,' the term 'mail order bride' tends to define the bride and groom solely on the basis of larger structural inequalities. It denies the possibility of Third World women (many of whom are educated adults) making logical, wise and active choices. While such terms may mobilize sympathy for foreign women as 'victims' they also reinforce certain preexisting stereotypes of Asian women. This may be beneficial in bringing about support for US legislation to protect those who end up in highly abusive marriages (Simons 1999), but it also makes it difficult for correspondence marriages to be understood in terms that are similar to other marriages. ${ }^{7}$

\section{Writing against labels}

So far, I have shown how images of maids, sex workers, and brides from Asia have been blurred in cultural studies discursive analyses, as well as in more activist-oriented antitrafficking literature. Next I turn to two short ethnographic sketches to further interrogate notions of 'mail order brides' and trafficked women. Like several recent studies of migrant wives, these sketches complicate the idea of 'mail order brides' as trafficked victims and point instead to their experiences and expressions of agency (Roces 2003; McKay 2003; Nakamatsu 2003; Tibe-Bonifacio 2003).

I met Bob and Faith, ${ }^{8}$ a Filipino-US couple, in the Philippines in the late 1990s. They had been married over 15 years and had two children together. They had met in the early-tomid 1980s when Faith was in her early 20s and Bob in his 50s. Bob had been widowed from his wife of several decades, and was devastated by her death. Around the same time, he underwent surgery. He was highly impressed by the care given to him by the Filipino

\footnotetext{
${ }^{6}$ This is not to suggest that men had no sexual fantasies related to images of innocent looking women. However, my point is that the discursive analyses of such images usually highlight and dwell on sexuality, whereas the men and women consciously and intentionally distanced themselves from what they considered a 'demeaning' interpretation.

${ }^{7}$ Foreign brides who are married for less than two years and whose marriages dissolve, for example, can easily lose their claim to permanent residence in the United States. This means that women may remain in unhappy marriages longer than they otherwise might out of the fear or stigma of being required to return home.

${ }^{8}$ All names are pseudonyms.
} 
doctor and nurses. A Filipina nurse gave him the addresses of some friends in the Philippines, and urged him to write to them. Shortly afterwards he embarked on a long voyage, during which time he wrote letters to several women in the hope of eventually 'remarrying and starting over.' Originally Bob had not written to Faith but to a friend of hers. The friend already had many pen pals so she passed his letter on to Faith. Bob and Faith then corresponded for many months, during which time Faith turned down an opportunity to emigrate to Canada (sponsored by her aunt); then he came to visit her in the Philippines.

Faith described her respect for Americans, spoke of the many Filipinos she knew who had emigrated to America, and of her attraction to a man who 'offered the love of a father, grandfather and husband combined in one.' Within days, after several chaperoned dates, Bob proposed (requesting her father’s permission, following Filipino custom). Faith's parents supported the marriage but insisted that they have a church wedding in the Philippines, rather than take the faster emigration route of getting a fiancée visa and marrying in the United States, for the sake of family honor and to protect Faith's reputation.

Bob’s adult children opposed their marriage. His son urged him to make Faith sign a prenuptial agreement, and his daughter-in-law warned him that Faith was a 'prostitute' or a 'gold digger.' Faith felt hurt, but understood that they were concerned about their father; eventually she won them over. Faith said that she never regretted her decision to marry Bob. She became a US citizen and they had two children. For several years, while they lived in the United States, she was lonely and homesick. After his retirement, she convinced Bob to move back to the Philippines to be near her family, where they could also afford to hire a 'helper' and a cook.

Like most of the couples I met, Bob and Faith fit certain stereotypes and dispelled others. The age difference of over thirty years was one of the largest of any couples I knew, but their marriage seemed solid and they seemed compatible (to me and to some mutual acquaintances who knew them far better than I did). Before marriage Faith's family's 
economic situation was not good. Nevertheless, had her main motive been to emigrate to the West, she had an opportunity to do so that she turned down before meeting Bob in person. Once a US citizen, she opted to return to the Philippines. Although Faith would have liked to have a part time job, she agreed not to work because of Bob. Bob, on the other hand, compromised in moving back to the Philippines. Although he was happy living there and was well integrated into the upper-middle-class Filipino community, he also missed the United States. Bob’s adult children’s initial suspicions about Faith’s motives and character are fairly common among the friends and relatives of men who are married to foreign women. This story illustrates both the popular blurs that may be prompted by Third World women who perform various forms of reproductive labor, as well as the subtle differences and motivations that can never be fully represented in a simple modernization narrative.

Ping was a 50-year-old divorcee from Beijing when I met her in the 1ate 1990s; Elvin was a 65-year old artist and lawyer from California. They had met over the Internet, on a web site where men and women enter their names, photographs, and introduce themselves, and where a fee is only paid at the point when someone (a man or woman) chooses to correspond with a particular person. ${ }^{9}$ In Beijing Ping lived in a nice apartment with her adult son and had a job as a librarian for a large private company. Elvin was also divorced with adult children and was semi-retired. Typical of many couples I met, they got to know one another over a yearlong period of correspondence via E-mail and Internet chat. Citing the fact that single men in Beijing were only interested in very young women, and concerned that she could not meet a Chinese man who was educated and shared her 'cultural' interests, Ping was attracted to Elvin for his artistic and intellectual pursuits. Ping thought Elvin was interested in meeting a Chinese woman because he had a friend with a Chinese wife, and he was attracted to what he thought was less materialism among Chinese women. They met in person when he came to Beijing for a two-week visit. At the end of the visit they continued to correspond and Elvin proposed.

\footnotetext{
${ }^{9}$ Some web sites are free to submit information but charge a few dollars for access to someone's contact information. In 1998 a six-month membership cost between US\$40 and \$150. In some clubs this entitled members to free access to all listings; in others E-mail addresses required no further payment but additional fees were charged for mailing addresses (see Constable 2005b).
} 
When I first met her, Ping was carefully weighing Elvin’s proposal. Eventually, she agreed to go to the United States on a 'fiancée visa' for 90 days, after which time she was required by law to either marry him or return to China. Although she was not certain about Elvin (and she wished that the visa allowed them more time together before having to marry), her visit reassured her and she agreed to marry him. Their marriage was rocky. Elvin was not physically violent, although Ping had once been so angry that she threw something at him, but he was uncommunicative and increasingly critical of her demands. As she explained, he was insensitive to her loneliness, expected her to be satisfied working and staying at home, and he provided her with little emotional or material support. She took a minimum wage job to contribute to their expenses. At various points she threatened to leave. She returned temporarily to China, but returned to the United States to try again. The relationship was turbulent. She mentioned looking forward to the 'two year mark' in their marriage. When they crossed that watershed she could apply for unconditional permanent resident status, even if she and Elvin split up. Ping explained that part of the problem was that Elvin thought he 'owned' her. He at once resented her attempts to gain greater personal and economic independence, and also refused to offer her greater financial or emotional support. By 2005, she had obtained a divorce and was living in the United States as a permanent resident.

Such stories point to a problem with the assumption that 'mail order brides' are trafficked victims. Ping made a reasonably well-informed decision on the basis of what she knew about Elvin (from a year of correspondence, his two-week visit in China, and her twoand-a-half-month visit in the United States). This might suggest that she knew too much to be considered an innocent victim, but others might argue that she was trafficked by virtue of the wider structural inequalities between the United States and China, the false promises and assurances that Elvin made before they were married, and her vulnerability as a foreign bride who would have to return to China permanently and lose her right to US residence if she did not remain married to Elvin for two years. Yet the notion of coercion and trafficking is confounded here by Ping's 'white collar' identity in China, and her low wage and emigrant status in the United States. Had she been poorer, younger, 
and less willing to return to China, she might better fit the stereotypical image of a 'mail order bride.’

\section{Productive blurs}

So far, I have argued against unproductive blurs, but must acknowledge an intellectual debt and a link to the work that has been done theorizing sex work and prostitution. Because sex work, correspondence brides, and domestic workers are similarly positioned discursively and at times structurally, such links can be highly productive. ${ }^{10}$

Kamala Kempadoo's work has been especially helpful in my analysis and critique of the literature on 'mail order brides.' She argues that Third World prostitutes are often described by terms such as 'slaves, trafficked, and victims' evoking 'images of helpless, ignorant, dependent women and girls' despite the fact that many sex workers suggest that we understand prostitution very differently as 'work within a clearly defined industry, as a survival strategy, or as a way of making do when other options are limited or closed' (1999, 225). Kempadoo asks whether we should thus read sex workers' views as 'false consciousness' or as a simplistic adoption of western discourses on prostitutes' rights? In keeping with studies and analyses that call for a shift away from 'simple hierarchies and dichotomies to the problematization of multiple spaces, seemingly contradictory social locations and plural sites of power' (234) she suggests that we pay greater attention to expressions of sex worker's agency, to see how they have resisted and contested 'oppressive and exploitative structures as well as the visions and ideologies inscribed in women’s practices.' This move 'is an attempt to position sex workers as actors in the global arena, as persons capable of making choices and decisions, that lead to transformations of consciousness and to decisions in everyday life’ (233). Kempadoo identifies Third World sex workers as 'one of the last sites of gender relations to be interrogated through a critical feminist lens that assumes that women are both active subjects and subjects of domination' (234).

\footnotetext{
${ }^{10}$ This is not to deny possible real connections between various categories of migrant women. For connections between domestic workers and correspondence brides, and for an example of a domestic worker who is also a marriage migrant, see Constable 2003b. See also Piper \& Roces 2003 for several insightful examinations of connections between work and marriage migration.
} 
So-called 'mail order brides' are similarly depicted as trafficked victims in need of rescue. And like those who 'fight for changes in the sex industry —and not for its abolition,' and who attempt to represent a different perspective, they are also subject to the charge of 'false consciousness' (Kempadoo 1999, 234). In relation to the issue of 'mail order brides,' for example, the PWC criticizes any 'narrow definition' of trafficking that seeks to isolate issues of abuse and coercion, a position that they suggest is 'being peddled by feminists, especially those from the North, who seek to legalize prostitution as a legitimate form of “work”' as a ‘reprehensible position' (PWC 2000, 1).

In keeping with Kempadoo's arguments, and in contrast to the PWC perspective, I suggest that an awareness of women's agency does not require that we ignore or accept structural inequalities and gendered abuses. If we pay closer attention to women's own attempts - through their words and actions - to counter or resist, and in some cases strategically embrace, the very images of submissive wife or passive sex object that are uncritically reproduced in the anti-trafficking literature, then we may avoid reproducing the notion that women's subservience and victimization is a natural and expected outcome. It seems ironic that some of the activist groups that most strongly oppose the demeaning treatment and condescending images of women, ultimately traffic in those very images themselves.

Unlike sex worker activists, however, there exists no loud or active debate among selfascribed 'mail order brides' who are fighting for rights and representation. As Tolentino suggests, this may be because 'the existence and operations of mail order brides' is 'poised to conceal aspects of women's pasts, thus making ethnography much more difficult to undertake' $(1996,51)$. When such ethnographic studies are conducted they generally draw on the experiences of women in shelters, or those whose relationships have, by definition, already failed (Julag-Ay 1997; Abraham 2000) ${ }^{11}$ I have found that foreign brides usually have little reason to identify themselves as a group on the basis of how they met their spouses (Larsen 1989 is an exception). If we listen carefully, we may 
hear the voices of immigrant wives, but most have little reason to identify themselves as or to reply to the name of 'mail order brides' or trafficked women.

\section{Conclusion}

My primary concern has not been with the fact that there exist three separate bodies of literature on brides, maids, and sex workers, or with the potential benefits of looking at these sorts of gendered migration in combination, but with the problematic ways in which they are sometimes assumed to be one and the same. The broad underlying assumption that is more overt in some activist literature than in more narrowly academic sources is that they are all part and parcel of 'the traffic in women.' Given a tendency among some academics and activists to all-too-readily blur the differences between various migrant women under the rubric of 'trafficked women,' my aim is to contribute to an ethnographically-based critique of the notion of migrant women as simply passive victims, and to illustrate some of the ways in which the victim-agent dichotomy falls short of providing us with a useful framework for understanding the lives, choices, experiences, and difficulties faced by migrant women.

My argument has drawn inspiration from the literature on sex workers that criticizes the dichotomy between innocent victims in need of rescue and immoral women deserving of what they get (Doezema 1998; Kempadoo 1999). This critique applies to the treatment of foreign brides in the United States, where those who are deemed to have unknowingly entered bad marriages on good faith (as innocent victims) are entitled to make legal claims to remain in the country as permanent immigrants and eventually to become citizens, whereas those who are deemed to be immoral women who entered the marriage on false grounds are not entitled to legal protections and immigration rights (Simons 1999; Meng 1994).

Women's ability to make a case to stay in the United States often depends on their ability to be seen as victims, rather than as women who entered marriages as equals or near equals and whose marriages failed. In other words, women whose marriages fail before

${ }^{11}$ Studies by Ordonez 1997, Roces 2003, and Tibe-Bonefacio 2003 are very noteworthy exceptions. 
two years are up can only make a claim to remain in the country if they can prove that they entered the marriage in good faith and that they have suffered abuse. ${ }^{12}$ The examples presented above support the idea that coercion, force, and agency are extremely hard to gauge or measure, and that they also vary through time, making it impossible to label all migrant women (maids, sex workers, correspondence brides) as trafficked, or to suggest that they are ever outside of a system of power and inequality.

The significant differences and variations in women's migrant experiences, and the difficulty in labeling them all as 'coerced,' point to the need to rethink the value and utility of the notion of 'trafficking.' Although migrant women's experiences — be they brides or workers or both-may indeed be similarly structured by broad factors such as class, race, ethnicity, nationality, and gender, women's experiences may also differ both among and between these categories and those of emigrant wife and emigrant worker. Trafficking overlooks many important issues including the distinction between women workers who are cognizant of selling their sexual or other labor, and correspondence brides who (like other brides) contribute reproductive labor but do not consider their sexual acts or their household work a commodity.

Although there are analytical, theoretical, and ethnographic insights to be drawn across the literatures on women migrants of various types, there are also risks in attempting to construct links and labels that the women we write about would not recognize or welcome. The fact that most correspondence brides would not recognize themselves in discussions of 'mail order brides' and trafficked women, or in discussions that suggest that they are somehow like prostitutes or maids, should be a cause for concern.

Identifying whom we are talking to and about by the labels they would recognize and respect, would seem be a fundamental step in the right direction for scholars, activists,

\footnotetext{
${ }^{12}$ This legal situation can have negative implications for both spouses. It can pressure women to put up with abusive marriages, it can provide men with greater opportunity to subject foreign wives to abuse, and it can cause women to make or exaggerate accusations of abuse in order to make claims to remain in the country. US legal restrictions make it difficult for women to leave unhappy marriages that do not involve abuse.
} 
and policy makers. Legislation and advocacy efforts that are directed toward 'trafficked women' or 'mail order brides' prematurely exclude foreign brides (and their husbands) who would not identify themselves or their marriages in such terms. Attempts to communicate with, advocate for, and provide support for foreign brides, would benefit by dropping the 'mail order bride' label altogether, considering instead the shared and differing needs and interests of immigrant women. The trafficking label also requires critical rethinking. From a practical perspective its adoption is closely linked to sources of funding. But its whole-scale adoption has served to blur distinctions between different sorts of migrant women and their needs and interests. 


\section{Reference list}

Abraham, M. 2000, Speaking the Unspeakable: Marital Violence Among South Asian Immigrants in the United States, Rutgers University Press, New Brunswick, NJ.

Barry, K. 1992, 'Sexual Exploitation Violates Human Rights', Coalition Against Trafficking in Women, Fall 1992 [Online]. Available: http://www.uri.edu/artsci/wms/hughes/catw/barry.htm [Accessed 5 October 2003.]

Cheng, S. 2002, 'Changing Lives, Changing Selves: “Trafficked” Filipina Entertainers in Korea', Anthropology in Action 9, 1, 13-20.

Chin, K. L. 1994, 'Out-of-Town Brides: International Marriage and Wife Abuse Among Chinese Immigrants', Journal of Comparative Family Studies 25, 1, 53-71.

Constable, N. 1997, Maid to Order in Hong Kong: Stories of Filipina Workers, Cornell University Press. Ithaca, NY.

2003a, Romance on a Global Stage: Pen Pals, Virtual Ethnography, and 'Mail Order' Marriages, University of California Press. Berkeley, California. 2003b, 'A Transnational Perspective on Divorce and Marriage: Filipina Wives and Workers.' Identities: Global Studies in Culture and Power 10, 2, 163-180. 2005a, 'Introduction: Cross Border Marriages: Gender and Mobility in Transnational Asia’ in Cross Border Marriages: Gender and Mobility in Transnational Asia, N. Constable (ed.) University of Pennsylvania Press, Philadelphia, Pennsylvania, 1-16. 2005b, 'A Tale of Two Marriages: International Matchmaking and Gendered Mobility' in Cross Border Marriages: Gender and Mobility in Transnational Asia, N. Constable (ed.) University of Pennsylvania Press, Philadelphia, Pennsylvania, 166-186.

Doezema, J. 1998, 'Forced to Choose: Beyond the Voluntary v. Forced Dichotomy’ in Global Sex Workers: Rights, Resistance, Redefinition, K. Kempadoo and J. Doezema (eds.), Routledge, New York, 34-50.

Ehrenreich, B. \& Hochschild, A. R. (eds.) 2002, Global Woman: Nannies, Maids, and Sex Workers in the New Economy, Metropolitan Books, New York.

Gamburd, M. 2000, The Kitchen Spoon's Handle: Transnationalism and Sri Lanka's Migrant Housemaids, Cornell University Press, Ithaca, NY.

Glodava, M. \& Onizuka, R. 1994, Mail-Order Brides: Women For Sale, Alaken, Fort Collins, Colorado.

Halualani, R. T. 1995, 'The Intersecting Hegemonic Discourses of an Asian Mail-Order Bride Catalog: Pilipina “Oriental Butterfly” Dolls for Sale’, Women’s Studies in Communication 118, 1, 45-64.

Holt, E. M. 1996, 'Writing Filipina-Australian Bodies: The Discourse on Filipina Brides’ in Philippine Sociological Review 44, 58-78.

Julag-Ay, C. 1997, ‘Correspondence Marriages Between Filipinas and United States Men’, PhD Dissertation, University of California at Riverside.

Kempadoo, K. 1999, 'Slavery or Work? Reconceptualizing Third World Prostitution', Positions 7, 1, 225-37.

Kempadoo, K. \& Doezema, J. (eds.) 1998, Global Sex Workers: Rights, Resistance, Redefinition, Routledge, New York.

Larsen, W. 1989, Confessions of a Mail Order Bride: American Life through Thai Eyes, New Horizon Press, Far Hills, NJ.

Marchetti, G. 1993, Romance and the Yellow Peril: Race, Sex and Discursive Strategies in 
Hollywood Fiction, University of California Press, Berkeley, California.

Maher, K. 2003, 'Gendered Migrations of Sex Workers, Domestic Workers, and Correspondence Brides', International Migration of 'Traditional Women', Center for Comparative Immigration Studies, University of California at San Diego. October 23-26.

McKay, D. 2003, 'Filipinas in Canada-De-skilling as a Push toward Marriage' in Wife or Worker? Asian Women and Migration, N. Piper \& M. Roces (eds.), Rowman and Littlefield, New York, 23-51.

Meng, E.1994, 'Mail-Order Brides: Gilded Prostitution and the Legal Response' in Michigan Journal of Law Reform 28, 197-248.

Mohanty, C. T. 1991, 'Under Western Eyes: Feminist Scholarship and Colonial Discourses’ in Third World Women and the Politics of Feminism, C. T. Mohanty, A. Russo \& L. Torres (eds.), University of Indiana Press, Bloomington, 51-80.

Nakamatsu, T. 2003, 'International Marriage through Introduction Agencies: Social and Legal Realities of 'Asian'’ Wives of Japanese Men', in Wife or Worker? Asian Women and Migration, N. Piper \& M. Roces (eds.) Rowman and Littlefield, New York, 181-201.

Narayan, U. 1995, “"Male-Order” Brides: Immigrant Women, Domestic Violence and Immigration Law', Hypatia 10, 1, 104-119.

Ordonez, R. Z. 1997, 'Mail-Order Brides: An Emerging Community’ in Filipino Americans, Transformation and Identity, M. P. Root (ed.), Sage Publications, Thousand Oaks, California.

Parrenas, R. S. 2001, Servants of Globalization: Women, Migration, and Domestic Work, Stanford University Press, Stanford, California.

Piper, N. \& M. Roces (eds.) 2003, Wife or Worker? Asian Women and Migration, Rowman and Littlefield, New York.

PWC (Philippine Women Centre of British Columbia). 2000, Canada: The New Frontier for Filipino Mail-Order Brides [Online]. Available: www Site of Status of Women Canada, http://www.swc-cfc.gc.ca/pube.html [Accessed 5 October 2003].

Robinson, K. 1996, 'Of Mail-Order Brides and “Boys’ Own” Tales: Representations of AsianAustralian Marriages’, Feminist Review 52, 53-68.

2001, 'Marriage Migration, Family Values, and the "Global Ecumene”, Conference on Migration and the 'Asian Family' in a Globalizing World, National University of Singapore, 16-18 April.

Roces, M. 2003, 'Sisterhood is Local: Filipina Women in Mount Isa Marriage' in Wife or Worker? Asian Women and Migration, N. Piper \& M. Roces (eds), Rowman and Littlefield, New York, 73-100.

Scholes, R. 1999, ‘The Mail Order Bride Industry and Its Impact on Immigration’ in International Matchmaking Organizations: A Report to Congress (Appendix A), [Online]. Available: http://www.ins.usdoj.gov/graphics/aboutins/repsstudies.Mobrept_full.pdf [Accessed 5 October 2003].

Simons, L. 1999, 'Mail Order Brides: The Legal Framework and Possibilities for Change' in Gender and Immigration, G. A. Kelson \& D. DeLaet (eds), New York University Press, Washington Square, N.Y., 127-43.

Suzuki, N. 1999, 'Women Imagined/Women Imaging: Re/presentations of Filipinas in Japan Since the 1980s', U.S.-Japan Women's Journal 19, 142-75. 2005, 'Tripartite Desires: Filipina-Japanese Marriages and Fantasies of Transnational 
Traversal' in Cross Border Marriages: Gender and Mobility in Transnational Asia, N. Constable (ed.), University of Pennsylvania Press, Philadelphia, 124-44.

Tajima, R. E. 1989, ‘Lotus Blossoms Don’t Bleed: Images of Asian Women’ in Making Waves: An Anthology of Writings by and About Asian American Women, Asian Women United of California (ed.), Beacon Press, Boston, Massachusetts, 308-317.

Thai, H. C. 2002, 'Clashing Dreams: Highly Educated Overseas Brides and their Low-Wage U.S. Husbands’ in Global Woman, B. Ehrenreich \& A. Hochschild (eds), Metropolitan Books, New York, 230-253.

Tibe-Bonifacio, G. 2003, 'Filipino Women and their Citizenship in Australia' Doctoral thesis, University of Wollongong.

Tolentino, R. B. 1996, 'Bodies, Letters, Catalogs: Filipinas in Transnational Space', Social Text 14, 3, 49-76.

United Nations, 'The Protocol to Prevent, Suppress and Punish Trafficking in Persons, [Online]. Available: http://www.unodc.org/unodc/trafficking_protocol.html [Accessed 9 February 2006.

USDOJ-INS (United States Department of Justice-Immigration and Naturalization Service). 1999, International Matchmaking Organizations: A Report to Congress, [Online]. Available: http://www.ins.usdoj.gov/graphics/aboutins/repsstudies.Mobrept.htm [Accessed 5 October 2003].

Villapando, V. 1989, ‘The Business of Selling Mail-Order Brides’, in Making Waves: An Anthology of Writings by and About Asian American Women, Asian Women United of California (ed.), Beacon Press, Boston, Massachusetts, 318-327.

Wilson, A. 1988, 'American Catalogues of Asian Brides', Anthropology for the Nineties, The Free Press, J.Cole (ed.), New York, 114-125. 